\title{
Numbered, weighed, cut!
}

At the origins of textile archaeology: the destiny of textile samples in museums late $19^{\text {th }}$-early $20^{\text {th }}$ century

Dénombrés, pesés, coupés! À l'origine de l'archéologie des textiles : la destinée d'échantillons textiles dans les musées à la fin du XIX $X^{e}$ siècle et début du XXe siècle

\section{Catherine Breniquet and Karina Grömer}

\section{(2) OpenEdition} Journals

Electronic version

URL: http://journals.openedition.org/artefact/6973

DOI: $10.4000 /$ artefact.6973

ISSN: 2606-9245

Publisher:

Association Artefact. Techniques histoire et sciences humaines, Presses universitaires du Midi

\section{Printed version}

Date of publication: 7 January 2021

Number of pages: 401-426

ISBN: 978-2-8107-0706-5

ISSN: 2273-0753

Electronic reference

Catherine Breniquet and Karina Grömer, « Numbered, weighed, cut! », Artefact [Online], 13| 2020,

Online since 23 December 2020, connection on 25 December 2020. URL : http://

journals.openedition.org/artefact/6973; DOI : https://doi.org/10.4000/artefact.6973

\section{@ $\odot \Theta \Theta$}

Artefact, Techniques, histoire et sciences humaines est mise à disposition selon les termes de la Licence Creative Commons Attribution - Pas d'Utilisation Commerciale - Pas de Modification 4.0 International. 


\title{
Numbered, weighed, cut!
}

\author{
At the origins of textile archaeology: the destiny of \\ textile samples in museums late $19^{\text {th }}$-early $20^{\text {th }}$ century \\ Catherine Breniquet et Karina Grömer
}

\section{Abstract}

A comparative study of the history of two archaeological textile collections is presented here. The first comes from the antique cemetery of Les Martres-deVeyre in France and is Roman. The second comes from the salt mines of Hallstatt in Austria and dates to the Bronze and Iron Ages. Both were discovered during the 19th century. Their respective history and study differ, depending on the museum where they are kept and on the scholarship traditions of the two countries. In France, the textile industry gave the first methodological frame for the study of archaeological textiles, while in Austria, laboratory's investigations brought the first results. The paper brings also information on the restoration and the museography of the two collections.

\section{Keywords}

textile archaeology, history of textile collections, textile industry, Martres-deVeyre, Hallstatt, Bargoin museum, Natural History Museum of Vienna

99 Catherine Breniquet et Karina Grömer, « Numbered, weighed, cut! At the origins of textile archaeology: the destiny of textile samples in museums late $19^{\text {th }}$-early $20^{\text {th }}$ century », Artefact, 13, 2020, p. 401-426. 


\section{Dénombrés, pesés, coupés ! À l'origine de l'archéologie des textiles : la destinée d'échantillons textiles dans les musées à la fin du XIX siècle et début du XX siècle}

\section{Résumé}

Nous présentons ici une étude comparative sur l'histoire de deux collections de textiles archéologiques majeures, celles des Martres-de-Veyre et d'Hallstatt, dans le but de documenter les origines, encore méconnues, de l'archéologie du textile. Découvertes dans les deux cas au XIX ${ }^{\mathrm{e}}$ siècle, ces collections datent de périodes différentes, l'époque romaine et l'âge du Fer, et ont connu des fortunes différentes en fonction des musées où elles ont été conservées et des traditions de recherche. En France, il s'avère que l'industrie textile a largement fourni les premiers cadres méthodologiques descriptifs, tandis qu'en Autriche, des approches scientifiques de laboratoire ont prévalu très tôt. Les questions de restauration et de muséographie sont également abordées.

\section{Mots-clés}

archéologie du textile, histoire des collections textiles, industrie textile, Martres-de-Veyre, Hallstatt, musée Bargoin de Clermont-Ferrand, Muséum d'histoire naturelle de Vienne 
extiles are so rare on archaeological sites in Central Europe (except in lakeside dwellings or bogs) that they were subject to surprising

1 manipulations in museums at the end of the igth century and during the first decades of the 2oth century. Like Balthazar's empire, they were numbered and weighed according to the textile industry's habits and disseminated all over Europe, and sometimes cut with scissors. Although problematic from today's perspective, these practices nevertheless provide a significant point of departure for the investigation of the history of textile archeology.

In this article, we would like to examine the beginnings of textile archaeology, considering these early museum practices often considered "extreme" regarding to our actual criteria, as an integral part of textile archaeology's history, and not only as the main concern of restoration and conservation treatments. ${ }^{1}$ Our study focuses on the experience gathered in two museums which keep early recognized archaeological textile collections of European origin, the Musée Bargoin of Clermont-Ferrand, today run by Clermont Auvergne Métropole (France), and the Natural History Museum in Vienna (Austria). The first textile collection is Gallo-Roman and comes from Les Martres-de-Veyre (France). The latter comes from the salt mines of Hallstatt (Austria) and dates from the Bronze and Iron Ages.

In our case studies, we focus on the find history and the early attempts of conservation and storage as well as first analyses of those textile collections. The two situations are different. After the 1920s, the Gallo-Roman textiles from Les Martres-de-Veyre were forgotten till the 1980s, while the Hallstatt textiles were regularly studied over the course of the 2oth century.

\section{Case studies: Textile collections from Les Martres-de-Veyre and Hallstatt}

In the I9th century, except for some specific dry areas as Egypt ${ }^{2}$ or wet as bogs in Northern Europe ${ }^{3}$ or lakeside dwellings in around the Alps, ${ }^{4}$ textiles were rarely recorded in archeological sites. The rarity of such artefacts

\footnotetext{
1. Cortopassi et Nowik, 2015, p. 6.

2. Calament, 2005.

3. Hald, 1980 for an overview.

4. Vogt, 1937.
} 
increased their value. Textiles from the huge collection gathered in Antinoé, Egypt were sent from the field to the Musée Guimet in Paris whose curators, overwhelmed by the enormous amount of material, dispatched them to different French provincial museums where corresponding mummies were held. ${ }^{5}$ The motivation in doing this was in part to share these discoveries with other museums and to make them available to a wider public, but also probably free up space in the storerooms! The scattering of the early collections depends in fact on the huge number of items unearthed, but also on the institutional organization of the different museums in Europe.

\section{Textile collection from Les Martres-de-Veyre}

The textile collection from Les Martres-de-Veyre comes from the GalloRoman graveyard found by workmen extracting clay for a nearby tile factory. The first grave was excavated in 1851. The workmen discovered a wooden coffin while digging in the clay. They opened it by its side and were immediately afraid as the deceased, a young girl, appeared to be merely "asleep". After this first surprise, they came back to the coffin and started to extract parts of the belongings, especially clothes together with bones. The next day, several scholars, the mayor of the town, and policemen came to the site and tried to collect what could be collected in a hurry. Pottery, baskets, shoes, textiles and even some parts of the coffin were sent to the museum in Clermont-Ferrand. Even now, it is difficult to say how many textiles were present in the coffin, because no proper documentation took place. The first publication mentions six but many more pieces were probably present. A large part of this first sample of textiles was studied by Charles Pagès in the beginning of the 20 th century. ${ }^{6}$

A more organized excavation at the graveyard of Les Martres-de-Veyre was set up in 1893, supervised by Jacques-Emile Kuhn. ${ }^{7}$ Several graves and cremation burials were then discovered. Most of the inhumations contained textiles, which were mostly brought back to the museum. In some cases, textiles are said to have been carelessly left at the edge of where they were sometimes taken by curious villagers. However, the collection could be

5. Calament, 1989.

6. Pagès, 1923.

7. Kuhn, Jacques-Emile, Les Martres-de-Veyre, Etudes archéologiques, unpublished, Archives départementales du Puy-de-Dôme, fonds Audollent, AD 6319 J 20. 
seen as "complete" in the sense that it is not known to have been scattered in several places. Unlike the textiles from the Hallstatt salt mine, those from Les Martres-de-Veyre stayed at the museum. As an evidence, when Kuhn's private archaeological collection was sold in 1907, there was not a single piece of textiles in the inventory records, but only Samian wares or small objects.

The most famous piece is the complete tunic (from Grave D), worldwide known, associated with leggings, socks and shoes. Other pieces are in a poor state of conservation, sometimes in pieces. Despite his efficient work in the field, Kuhn is now forgotten and his work has never been fully published. What is known from the excavations, was written as a kind of "summary" by Auguste Audollent, ${ }^{8}$ fellow of the Ecole française de Rome, professor of Classics in the local university since 1893, and director of the Bargoin museum in 1903. For obscure reasons, he never referred explicitly to Kuhn's work, probably because Kuhn had difficult relations with local scholars, complaining of the poor interest accorded to his discoveries, especially regarding textiles.

As a local academic, Audollent was somehow obliged to also conduct excavations on the site, which he did . well after in 1922-23. ${ }^{9}$ But, even with the discoveries of new graves and urns, the results remained less spectacular than the previous ones and were quickly and shortly published, without illustration. One of the graves, Grave I, which brought to light a wooden coffin with a skeleton associated with (at least) leg-bands in situ, was taken back to the museum where it remained closed and on display until 2014 ! Then, the opening of the coffin for dendrochronology ${ }^{10}$ analysis revealed the presence of several unknown textiles in a bad state of conservation.

There are an estimated 100 pieces in the textile collection of Les Martresde-Veyre, some of them complete, others fragmentary, which is exceptional for France. Their analysis started at the beginnings of the 2oth century. After gathering the information and re-numbering the graves, Audollent published his synthesis on the igth century's excavations. This publication remained our main source of information until the start of a new research

8. Audollent, 1923.

9. Audollent, 1922. Also A. Audollent, Mes voyages aux fouilles des Martres-de-Veyre, mardi 25 juillet 1922, p. 8-9, unpublished. Fonds Audollent, AD 6319 J 20.

10. Blondel, 2014. For the textiles, see Breniquet et al., 2017b. 
project, ArchéoMartres. ${ }^{11}$ The site was explored by several scholars during the I 9 th century, but the graveyard itself was not subject of excavations. Its precise location remained vague ${ }^{12}$ until the present and, more generally, archaeologists tried other field methods such as aerial surveys or rescue operations (mostly excavations). ${ }^{13}$ So far, no new pieces of textiles have been found. Except some stains on the tunic probably from contact with a metallic object, no mineralized textile on fibulae or coins are present. The reason is the disappearance in the field of this category of artifacts, most probably taken by strollers. Surprisingly however, some fragmentary pieces were rediscovered by Sophie Desrosiers in 1996 in the museum. ${ }^{14}$ Until now, we didn't know from which grave they came. But, as for Grave I, they probably came from another coffin kept and displayed in the museum, emptied after apparent flood damage. ${ }^{15}$

Careful reading of the publication and unpublished archive materials inform us that textile studies were entrusted to Auguste Audollent on the advice of Joseph Déchelette. ${ }^{16}$ Through his position at the university, Audollent was in contact with the scientific community of his time. However, as a classical archaeologist he was more concerned with the foundations of archaeology in France such as monumental architecture, pottery, and epigraphy, than with organic materials. It was Joseph Déchelette, who lived not far from Clermont-Ferrand and Lyons in Roanne, who suggested to Audollent after visiting the museum, to conduct a study of this exceptional textile collection. Déchelette was directly involved as he planned to write a pioneer work about the history of weaving in Gaul, with references to the discoveries around the beginning of the 20 th century in northern

11. The ArchéoMartres project, « La nécropole gallo-romaine des Martres-de-Veyre en contexte. Étude scientifique et valorisation des collections archéologiques gallo-romaines conservées au musée Bargoin ", is sponsored by the Direction Régionale des Affaires Culturelles of the AuvergneRhône-Alpes region and the Conseil départemental du Puy-de-Dôme since 2017. It merges the Musée Bargoin of Clermont-Ferrand, the University of Clermont Auvergne, the Clermont-Ferrand Maison des Sciences de l'Homme and the Institut national de recherches archéologiques préventives.

12. In 2017-2018, we succeeded in precisely locating the graveyard with inhumations and cremations which covers about $6000 \mathrm{~m}^{2}$. Forthcoming.

13. Lauranson, 2012.

14. Desrosiers and Lorquin, 1996, p. 56.

15. Unpublished result of the ArchéoMartres project.

16. Audollent, 1923, p. 4. 
Europe. ${ }^{17}$ However, to write such a synthesis, Déchelette needed both textile samples and a specialist in weaving. The Martres-de-Veyre collection was studied first for this purpose. Déchelette suggested Charles Pagès, a Professor of textile in the École de Commerce de Lyon and draftsman at the Tissages Déchelette, Delpierre \& $\mathrm{C}^{\mathrm{o}}$ in Roanne. ${ }^{18}$ Déchelette's family was among the industrial weavers of the area of Lyons, but had no direct connection to the silk industry. Déchelette himself was the president of the directorate of the family enterprise. His interest for archaeological textiles (and "ordinary" textiles) developed out of his professional activities and family traditions, an example of how deeply textile archaeology in France is connected to the textile industry. Pagès' study was integrated into Audollent's monograph on Les Martres-de-Veyre. Soon after, Pagès died in unknown circumstances, but his father gave Audollent permission to use his ready-to-publish work. ${ }^{19}$ After the First World War, it was probably hard for Audollent to find another textile specialist and finally, he did not study the textiles found during his own excavation campaigns of 1922-1923. Audollent remained a classical archaeologist for whom textiles are scientifically informative, but nonetheless anecdotal. However, we must acknowledge that he accomplished a great deal in disseminating knowledge of the site through lectures, published notes (especially in English journals) and the articles.

\section{Textile collection from Hallstatt}

An important part of the textile collections of Vienna's Natural History Museum derive from research activities at the site Hallstatt in Upper Austria—dating back to Johann Georg Ramsauers excavations in Hallstatt's salt mine and cemetery from 1846 on. ${ }^{20}$ After being incorporated into the Antiquities collections of the Habsburg family, the textiles were then

17. Audollent, 1923, p. 44. Letter from Déchelette to Audollent dated 22th november 1911, fonds Audollent, AD $6319 \mathrm{~J} 20$ : je rédigerai peut-être une étude d'ensemble sur les tissus préhistoriques et gallo-romains découverts en Europe. J'ai déjà un petit dossier, mais il est encore mince. Il me faudrait étudier les documents scandinaves, qui sont les plus abondants.

18. Letter from Déchelette to Audollent dated $20^{\text {th }}$ november 1911, fonds Audollent, AD 6319 $\mathrm{J} 20$.

19. Letter from Mme Déchelette to Audollent dated $1^{\text {st }}$ July 1921 informing him of the death of Ch. Pagès. Letter from M. Pagès father to Audollent dated $4^{\text {th }}$ July 1921, Fonds Audollent, AD 63 $19 \mathrm{~J}$.

20. For a detailed overview see Grömer et al., 2013. 
moved to the Prehistory Collection of the Natural History Museum which opened in $1889 .{ }^{21}$ The oldest textiles from Hallstatt salt mine date back to the Bronze Age ca. 1500-1100 BC, but the main corps comes from the Early Iron Age parts of the salt mine, dating from ca. 800-400 BC. Also, mineralized textiles have been found attached to metal objects in the graves of Hallstatt's Early Iron Age cemetery. ${ }^{22}$ We will focus here on the textiles from the salt mines.

Excavation activities at Hallstatt's salt mine were especially intensified from 1960 on by the excavators Fritz-Eckart Barth and Hans Reschreiter and were still being carried out by the Department of Prehistory, ${ }^{23}$ in 2020. As such, to date the textile collection from Hallstatt ${ }^{24}$ comprises more than 320 textile complexes, consisting of more than ca. 600 single fragments.

Due to the long find history and different circumstances of discovery and excavation, not all textiles from Hallstatt's salt mine are kept at Vienna's Natural History Museum. ${ }^{25}$ Some textile fragments remained in the village of Hallstatt itself, where they have been incorporated into the Museum Hallstatt and the Collections of the Salinen Austria AG, the company that runs the salt exploitation at Hallstatt today. Additionally, single textile items ended up in other Austrian museums such as the Museum Wels, the Nordico Museum Linz, the Study Collection of the Institute of Prehistory and Early History of the University of Vienna, Austria. Also some textiles were sent to foreign countries and can now be found at the National Museum of Denmark in Copenhagen and Harvard University's Peabody Museum, Cambridge, Massachusetts, USA.

The reasons for the dispersal of the textile collection from Hallstatt's salt mine are numerous and complex. The Hallstatt Museum has kept textiles found during the excavation of 1935, which was carried out by members of the museum. The administration offices of the Salinen Austria AG have also kept the numerous textiles found during their modern mining activities as well as some from the re-launching of excavations in 1960. The museums in Linz and Wels as well as the University of Vienna acquired

21. Heinrich, 2018, p. 8-13.

22. Grömer, 2014, p. 195-198, cat nr. HaZ-16 to HaZ-29; Taf. 4.

23. Detailed overview about the site, research history and different finds see Kern, Kowarik, Rausch, Reschreiter, 2008.

24. Overview in Grömer, Kern, Reschreiter, Rösel-Mautendorfer, 2013.

25. Grömer, Kern, Reschreiter, Rösel-Mautendorfer, 2013, p. 33-36. 
textiles from the salt mine from private collectors which were active in the region of Hallstatt, namely Dr. Pachinger, Dr. Much and Dr. Nusko, although it is not clear how they came into possession of these objects at the end of the I 9 th century and at the beginning of the 2oth century. The textile that ended up at Harvard's Peabody Museum, came from excavation activities conducted by the Countess of Mecklenburg carried out at Hallstatt cemetery in 1907. After her death, all items of the Mecklenburg collections were sold to institutions in the United States. ${ }^{26}$

The fate of the textile housed at the National Museum of Denmark in Copenhagen is interesting, as it was originally part of the collections of Vienna's Natural History Museum. As a result of exchanges of artefacts between European museums that was common practice at the beginning of the 2oth century, a textile sample (together with other finds) from Austria was sent to Denmark, enriching their collections. In exchange, some flint daggers and other artefacts from Danish sites were donated to the museum in Vienna.

\section{Attempts of the museums: Textile preservation, textile exhibition}

Museums face several challenges regarding the preservation, display and manipulation of organic samples for study. Both collections from Les Martres-de-Veyre and Hallstatt were, and still are, in good state of conservation. In the I 9 th and beginning of the 2oth centuries, museum curators and specialists from weaving schools tried several possibilities to preserve the specimens.

\section{Preservation and exhibition at the Bargoin museum}

Most, if not all, of the fragments from Les Martres-de-Veyre were preserved well, remaining supple and sometimes even complete. This exceptional preservation is probably linked to the presence of carbon dioxide in the soil, which infiltrated the coffins and stopped the bacteriological degradation of the organic materials. But this hypothesis has never been verified 
scientifically. Even now, more than 150 years after the discoveries, the pieces are still stable which facilitates their manipulation and futher analysis of the complete garments. Unfortunately, as for other French museums, archival material is lacking. We know that Jean-Baptiste Bouillet, the first curator, displayed some fragments of fabrics from Grave A. ${ }^{27}$ In 1903, the museum was relocated to the building presently occupied by the museum. Presenting this new museum in a catalogue, Audollent referred to its main sections: arts, lapidary, and archaeology. Fabrics, however, were omitted from the publication. ${ }^{28}$

However, through cross observation (unfortunately sometimes undated), we can see that the complete tunic from Grave D was first displayed vertically, on a wooden stick in an hexagonal glass case which contained other objects from the site installed in the centre of the first room of the museum, surrounded by paintings (Fig. 1a). ${ }^{29}$ Between 1968 and ca. 1980, it was also displayed vertically but flat and fixed by invisible nylon threads between two glass' panes (Fig. 1b). This layout was given up as it damaged the fabric due to the weight of the tunic. Finally, the tunic was displayed flat again but horizontal, in a showcase with an inclined bottom and two shelves untill 2006 (Fig. 1d). At present restored but still fragile, the tunic is kept in the storerooms.

One of the first curators of the Bargoin museum, probably Audollent, didn't hesitate to put the tunic on a mannequin as others did on living models (Fig. 1d) for a special exhibition or more probably for taking photographs for printing cards sold by the museum or local booksellers.

As far as we know, no attempt was undertaken to wash the textiles or to clean them from dust (except by shaking them in the field). We don't think they were ironed before the 1980s. On the request of Mr. PierreFrançois Fournier, one of the museum's curators, a model of the complete tunic with its leggings, was later drawn and published. ${ }^{30}$ We also know that a heavy wool lining was added to the tunic between 1893, date of its discovery, and 1982, date of its removal for restoration and introduction

27. Bouillet, 1861, p. $105, \mathrm{n}^{\circ} 137$.

28. Audollent, 1908.

29. Bouillet, 1861, p. 5.

30. Fournier, 1956. We have no information on the date and maker of the lining, maybe at the same moment than the drawing of the model. 
of a new silk lining sewn by Mrs Girault-Kurtzemann, who also treated fragments found infested by moths by Sophie Desrosiers in 1996. ${ }^{31}$

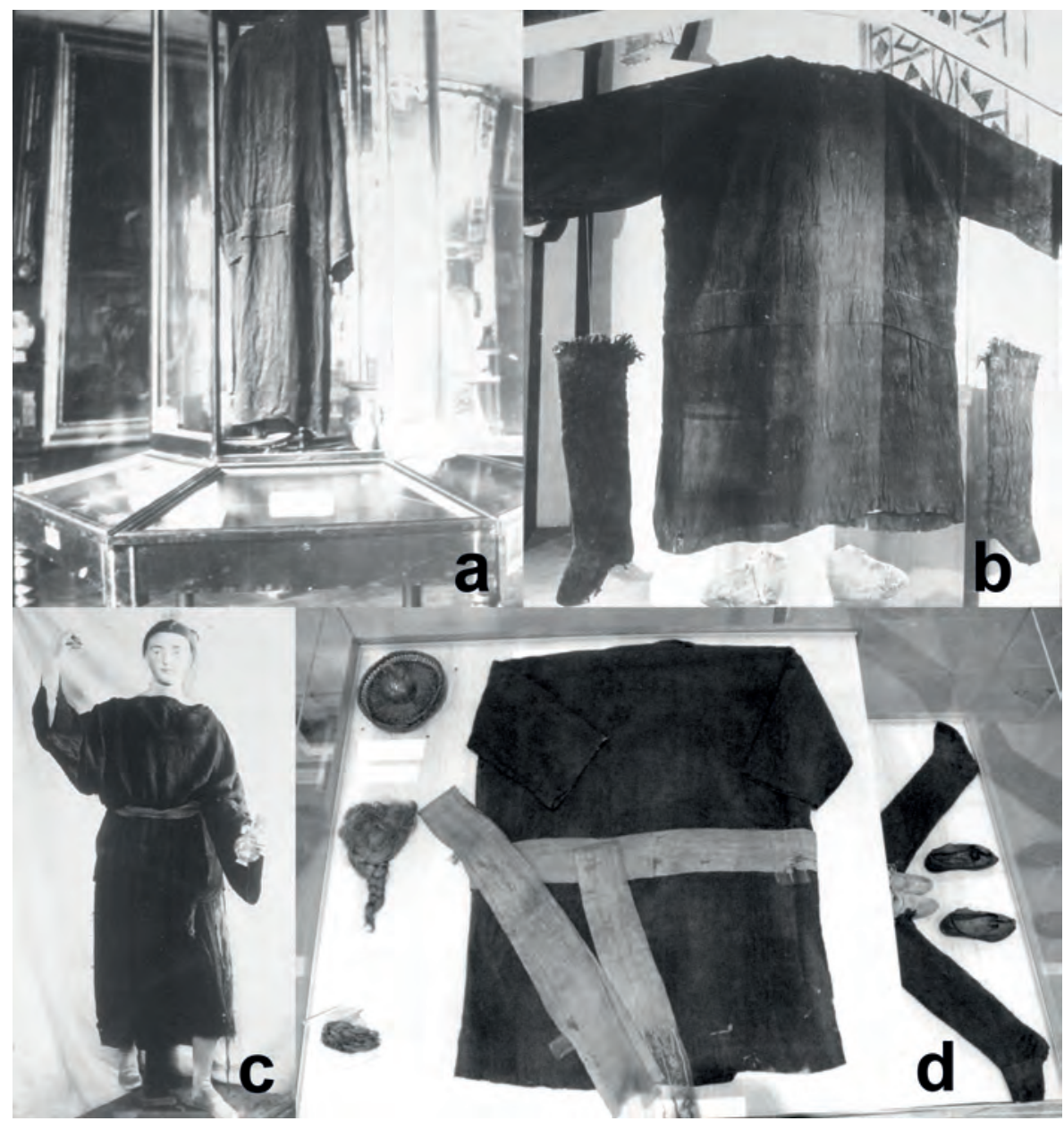

Fig. 1. - Evolution of the presentation of the complete tunic from Grave D, Les Martres-de-Veyre, in the musée Bargoin

a. The tunic in 1904 (?) under its hexagonal glass case.

b. The tunic displayed vertically between two glass panes (between 1968 and 1980).

c. The tunic on a mannequin, unknown date.

d. The tunic displayed horizontally in a showcase with inclined bottom (till 2006). Musée Bargoin

31. Desrosiers and Lorquin, 1998, p. 56. 
During all that time, the textile pieces were displayed without any specific care, especially in regards to lighting and climatic conditions. Now, most of the textiles and especially the complete tunic from Grave D are kept in storerooms and not displayed in the museum's exhibition rooms. Some pieces, such as the leggings are now visible in a reduced light inside a glass case, displaying also the leather shoes, a basket, some ceramics, the hairs, etc. in order to evoke the contents of the inhumations. However, it is planned to alternate exhibited pieces in order to prevent light damage.

The great novelty came from technical studies of archaeological pieces at the very beginning of the 2oth century. On the advice of Déchelette, Audollent sent 13 specimens from Les Martres-de-Veyre to Pagès. The samples are now kept in the museum in a sample box of cardboard and wood with drawers (L. 25,7 cm; H. $21 \mathrm{~cm} ; 1.14,5 \mathrm{~cm}$ ) (Fig. V, colour plates). In the final publication, Pagès mentioned that he received 11 pieces of small dimensions, ${ }^{32}$ often $10 \mathrm{~cm}^{2}$, but the box contains 13 specimens, all of which have handwritten notes made by by Pagès himself. It is possible that he received the collection in two parcels, as numbers 12 and 13 seem to have been added later on the drawer 5 .

The sample box in itself provides a lot of information. Ten "drawers" are introduced inside through grooves. Each contains a white sheet of cardboard covered by a sheet of black paper on which the textile samples are sewn. Pagès explained that he secured the textiles with a few stitches in black thread. Unlike the Hallstatt collection, samples from Les Martresde-Veyre were not glued or stabilized and exposed framed between glass plates. $^{33}$

The cardboard sheets are numbered, from 1 (on the top) to 10. Except for sheet $\mathrm{n}^{\circ} 5$, which holds 4 samples, the textile pieces are isolated. Pagès added the numbers and the direction of the warp on each sheet (Fig. V, colour plates). The provenance of the main collection is still debated among scholars from the ArchéoMartres project. The drawer $\mathrm{n}^{\circ} 5$ gathers very small fragments from Grave $\mathrm{D}$ which were parsimoniously cut from

32. Pagès, 1923, p. 59.

33. These practices are recorded for the Antinoé collection; we can deduce they were common in the museums. Calament, 2005, p. 254, but also for other collections from the musée du Louvre: Cortopassi et Nowik, 2015, fig. 1, p. 6 and Descamps et al., 2015, fig. 1, p. 72 (both from Greek origin); Fontan et Moulhérat, 2015, fig. 2, p. 26 (Tombeau des Rois). 
complete pieces: tunic, belt, socks' languet, and two fringes from the leggings (Fig. Vc, colour plates).

Most of the specimens in the box were directly cut with scissors from the original pieces. Clear cuttings with right angle are easily observable, sometimes with selvedges, borders or colored patterns (Fig. Vb, colour plates). It is not possible to know who cut the textiles, Audollent alone or on the request of Déchelette? Déchelette himself? Some pieces are deliberately fringed with the help of a needle, in order to count the number of threads in warp and weft (Fig. Vd, colour plates). This is clearly a technique borrowed from the textile industry, suggesting Pagès might be at the origin of this practice.

The box could have been made for museum purposes, or simply as a carry over from common textile industry practices. Such boxes can be used vertically or horizontally, for storage or for study. Audollent, perhaps inspired by Déchelette, could have planned to make a set of "bookcases" made of several drawers dedicated to the archaeological textile specimens, which would have illustrated the diversity of textile techniques of the Roman period. We have no other evidence of early conservation work.

\section{Preservation and exhibition of the Hallstatt Textiles at the Natural History Museum}

Due to preservation conditions in the salt mine (constant climate, humidity, salt penetration which hinders microbacterial activity), ${ }^{34}$ textiles from Hallstatt are in very good condition, retaining their elasticity and colour. For conservation purposes, salt had to be removed and items had to be dried and laid out ${ }^{35}$ — this was also understood by the people who found the first salt mine textiles in the I 9 th century. In those early days, the textiles were washed in the little stream that flows nearby the entry to the mine. Recent attempts have been made to understand fibre degradation in the salt mine textiles and the effect of historical conservation treatments. Wet cleaning with distilled water-enclosed in a protective fabric-is now the state of the art procedure, followed by laying out of the textiles

34. Grömer, 2016, p. 24-25.

35. Gengler, 2005; Miller 2005. 
according to their original position and storage using acid-free cardboard and untreated cotton beddings. ${ }^{36}$

Here we focus on historical conservation treatments and museum practices that had a negative impact on the integrity of the textiles.

In the early days of salt mine textile treatment at the end of the I 9 th and the beginning of the 2oth century, pieces of rock salt (Fig. VI, colour plates) were steeped in water with the textiles, thus washing the fragments quite thoroughly. The "left over" threads gained during washing have not been kept (as it is done nowadays). Even between 1960 and 1984, the wet extraction of the textiles from the embedding salt rock and subsequent washing was done to obtain "very clean" objects. Even common laundry detergents were used to get rid of dirt. ${ }^{37}$ At that time, Hans-Jürgen Hundt at the Römisch-Germanisches Zentralmuseum Mainz developed a preservation treatment meant to be dust-free which involved pressing textiles between two glass sheets, usually mounted with small plexiglass cubes as distance holders (Fig. VII, colour plates).

Other treatments were also applied to the salt mine textiles from Hallstatt. ${ }^{38}$ In the early 1900s, coloured impressions of some textile fragments after rinsing were made on card (Fig. VIIIa, colour plates), using the then-commonly accepted copying machine. The results are textiles that are pressed and deformed (Fig. VIIIb, colour plates). Restoration work in the first half of the 2oth century also involved stabilizers (Fig. IX, colour plates) that have been attached to items to prevent fraying. Textiles with such a treatment are stiff.

As far as can be reconstructed from old photographs, textiles from Hallstatt were exhibited along with other finds from that site since the opening of Vienna's Natural History Museum in 1889. Their display in cases without special climatic conditioning lasted for over 100 years, as well as their exposure to daylight and artificial light.

In the 1960s, the permanent exhibition of the Department of Prehistory was re-furbished ${ }^{39}$ and some textiles from Hallstatt thus hung, the textile

36. Gengler, 2005; Grömer and Reschreiter, 2013, fig. 12.

37. Gengler, 2005, p. 50.

38. Morelli, 2005.

39. Heinrich 2018, p. 15-17. 
display was placed in a dark area within the exhibition in order to avoid sunlight damage (Fig. 2). Artificial lightning had to be switched on deliberately by the visitors to see the textiles. This kind of display was removed in 2008. Since 2015 a newly installed exhibition presents the Hallstatt textiles lying flat in climatic displays with reduced light. ${ }^{40}$ Storage methods $s^{41}$ for the archaeological textiles kept at the Natural History Museum, which are not on display have also varied somewhat over the long history of finds (from 1846). Up to the 1980s, textiles were stored in wooden drawers below display cases in the exhibition rooms. After Hundt's work, they were kept in the anteroom of the restoration workshop in a metal cabinet. In 1998, they were transferred with the cabinet to the climate archive at the Museum.

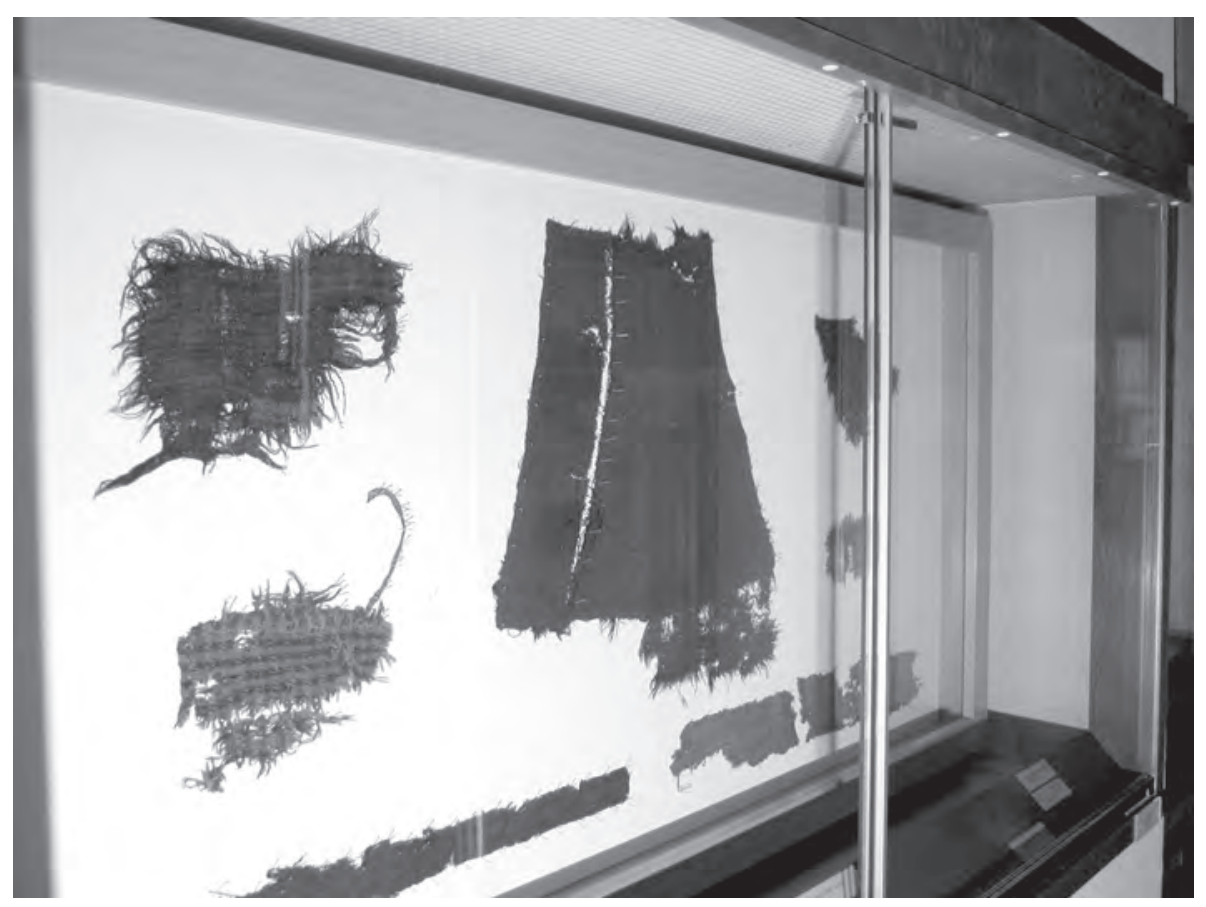

Fig. 2. - Textiles on display at the Natural History Museum Vienna between 1967 and 2008

(c) Natural History Museum Vienna

40. Reschreiter, 2018, p. 175-176.

41. Gengler, 2005, p. 55-61. 


\section{Beginnings of textile archaeology Textile industry and textile archaeology, studying textile in France as seen from Les Martres-de-Veyre}

In France, especially where textiles are part of local or regional heritage, the first scholars who studied archaeological textiles came from the textile industry. Conventional archaeology, even if textile collections have been available, had no appropriate methods at the beginning of the 2oth century, and focused mainly on aesthetic, stylistic or trade approaches. Until the Second World War, the area of Lyons was famous for its textile industry (especially its silk products). It is highly probable that, found in another place, the archaeological textiles would never have been subject to study due to the poor interest for textile in French archaeology at the time. Déchelette, with his personal background in the textile industry, understood that a technical study would bring new insights and convinced Audollent to send some specimens to Pagès.

Pagès was among the first scholars to develop an interest for daily life textiles from archaeological contexts. For his pioneering study he adopted professional methods he used as a teacher and designer in the textile industry. $\mathrm{He}$ gathered technical parameters by observation, counting and weighing - as it was proper industry methodology at that time. His method takes into account the joint study of the warp and the weft, in order to define the weave and the density of threads in both systems. He succeeded in identifying the warp from the weft by the higher diameter of threads and the strength. He demonstrated how some technical details such as the presence of borders, or finishing treatments enabled the fabrics to be oriented and revealed how they were woven. Warp for instance is systematically pointed out on each sheet. Each thread is described, single or plied yarn, clockwise or opposite (in modern terms: S- or Z-spun). The twist of the threads is measured or at least estimated by meter. It is difficult to know if he used an industrial torsiometer or not. He also added details that are not used in modern archaeological textile studies such as the yarn length in regards to the weight (what we call today the "Tex") or the shrinkage linked to the weaving process. 
In order to identify the raw material, he studied the samples with a microscope (x 300), concluding that they are in wool (probably through the observation of scales) and compared them with different wool samples. He confirmed his observations by burning some tiny pieces (threads or detached parts) and observing the combustion process and its characteristic smell (burned horn). He also gave some general information on the dyed pieces but without risking an identification of the dye. ${ }^{42}$

The second step of his analysis was the study of the weave. He recognized three types: tabby, twill and composite (diamond twill or chevron twill). In order to draw properly the weave and to specify the numbers of threads by centimeter in both systems, he fringed the samples.

Surprisingly, Pagès never went on to identify a specific type of loom, nor expressed the need for archaeological context. Coming from the textile industry, his main concern was most likely the technical information necessary for making contemporary copies of antique textiles, ${ }^{43}$ and not the reconstruction of the loom. The archaeological perspectives were left to Déchelette whose studies remained austere and hard to understand for a non-specialist. Audollent himself used some parts of it, sometimes without a clear understanding, confusing the textiles and mixing information.

Pagès is now forgotten and his pioneering study of this Gallo-roman collection remained unknown for a long time as both he and Déchelette died soon. However, Pagès' study is a remarkable attempt to analyze unusual archaeological material from a Classical cultural context. Nonetheless, the great "architect" of this scientific textile adventure remains Déchelette. Half Classic Archaeologist, half Prehistorian, he was first to understand the necessity of a new approach to the material, which he forged through his knowledge of the industry and personal experience in a weaving factory. ${ }^{44}$

42. Pagès, 1923, p. 83.

43. Pagès, 1923, fig. 1-4, p. 109-112.

44. As said above, Déchelette planned to write an innovative synthesis on the Gaulish textiles. The chapter VII of his Manuel d'Archéologie préhistorique, celtique et gallo-romaine, published in 1914, deals with clothes, personal ornaments and toilet objects. The main sources he used are the ancient writers, not archaeology, as his study was not already written. Alber Grenier, who somehow continued his work in his Manuel d'archéologie gallo-romaine of 1958, opened the way to a quiet different perspective: monumental archaeology, ancient roads, navigation and land use. Textile archaeology was there definitely put aside. 


\section{Textile research at Natural History Museum Hallstatt textiles}

When they were first discovered in 1846, the textiles found in Hallstatt's saltmine were immediately understood to be valuable artefacts from the past, but through comparison to textiles of the I 9 th century. To cite the finder, Johann Georg Ramsauer ".... some pieces of different woolen fabrics, their production to be recognised by skilled people; the same quality like recent wool cloth, but if they have not been enclosed by salt rock, somebody would recognise them as cheating [i.e. as modern and not as thousands of years old]" (Fig. X, colour plates). ${ }^{45}$

As such, the textiles were soon described in the manner of folkloristic artefacts, just given some basic data such as "Woven cloth of coarse sheep's wool, torn in several places, $138 \mathrm{~cm}$ long, $100 \mathrm{~cm}$ wide". ${ }^{46}$ In 1927, some fabrics along, with other leather and fur objects, were brought to Halle an der Saale in Germany for scientific conservation and analysis. But those objects seem to have been lost during the Second World War and even a scientific report never arrived at the Natural History Museum in Vienna.

It was not until the late 1950s, that Hans-Jürgen Hundt (then at the Römisch-Germanisches Zentralmuseum Mainz) started to describe the salt mine textiles in a more technical-analytical way. His pioneering work included a detailed catalogue of more than 100 textiles, at the height of its time, also including thread counts and measurements of yarn sizes (he measured yarn diameters). ${ }^{47}$ In a then innovative, interdisciplinary approach, he also asked different specialists from other disciplines to help him identify the fibres. One of those specialists was A. Satlow, ${ }^{48}$ then at the Materials Research Institute at RWTH Aachen. Hundt also contacted the forensic specialist W. Specht, then at the Bavarian Criminal Investigation Department in Munich. Specht used methods common on crime scene investigations in the mid 2oth century, such as various burning tests and microscopy, spectography and chemical tests. They found that samples of naturally pigmented wool (brown and white) had changed into more gree-

45. Ramsauer, 1850, first page.

46. E.g. Stapf, 1886, p. 409.

47. Hundt, 1959, 1960, 1987.

48. Satlow, 1959, p. 96-97. 
nish-brownish colour by copper and iron compounds from the salt mine. ${ }^{49}$ Plant fibres have been analysed by the botanist Maria Hopf from Mainz. ${ }^{50}$ After Hans-Jürgen Hundt's pioneering work, systematic research on the Hallstatt textiles was carried out from the late 1990s on by members of different universities, notably in large-scale international research projects during the early $\mathrm{XxI}^{\text {st }}$ century, which also included intensive interdisciplinary studies of dyestuffs and fibres. ${ }^{51}$

\section{Conclusions: old collections, new perspectives}

Despite the diversity of contexts explored here, working on old collections allows us to understand their reception at the time of their discovery from the perspective of research history. In France, organic materials remain rare due to preservation conditions in the field. Archaeology at the end of the Inth century was also dominated by the monumental Classical approach. Thus, textiles were considered with two different perspectives. Firstly, as most of the biggest collections come from funerary contexts, they allowed strange "mystic" reenactments during lectures where living models were draped with ancient rags. This practice was used by Albert Gayet with the Antinoé collection. ${ }^{52}$ The second is the scientific one adopted by different museums: understanding the fibers, the techniques, the importance of the textiles in ancient daily life, etc. As discoveries were scarce and textile archaeology was not at that time an autonomous discipline, curators explored many ways of preserving and displaying this uncommon material. Meanwhile, they sought the help and expertise of the textile industry, which set up the scientific frame for observing and collecting technical parameters. Most of these industrialists and even textile industry artisans opened the way for textile archaeology: Charles Pagès, Emile Cherblanc, Rodolphe Pfister, Félix Guicherd, Hubert Masurel are amongst the most important of such actors in France. If their scientific publications are well known, the link between textile archaeology and the French textile industry needs to

49. Specht, 1959 , p. 97-100.

50. Hundt, 1960, p. 130.

51. See Grömer and Reschreiter, 2013.

52. Calament, 2013, p. 34-35. 
be further explored. Considering the Martres-de-Veyre collection, the first interest initiated by Déchelette was not followed by scholars. Of course, several Gallo-roman textile finds came to light during excavations, even in Les Martres-de-Veyre by Audollent himself in the 1920s, but they remained isolated or not studied at all. A real epistemological approach emerged only in the 1980s-1990s with a new interest for archaeological textile and garments facilitated by new field methods and new scientific approach. ${ }^{53}$

In Austria, scientific analytical research on textiles from archaeological excavations was started with Hans-Jürgen Hundt in the late 1950s. Textiles from the salt mine Hallstatt played a major role in these studies. ${ }^{54}$ Later, textile studies were done with artefacts from the salt mine Dürrnberg and selected cemeteries dating from the Iron Age and Early Medieval era. ${ }^{55}$

Unlike France, where the textile industry was pivotal in establishing analytical approaches and drawing attention to such archaeological material, in Austria, science surrounding archaeological textiles was informed by long scientific traditions of Germany and Scandinavia. Early German textile researchers like Karl Schlabow ${ }^{56}$ who worked with bog textiles from Northern Germany, can be named here. For textile archaeology in Austria, Lise Bender Jørgensen's late 1980s research project was also very important. In her European-wide diachronic study of textile types in Prehistory and the Early Medieval era, ${ }^{57}$ she concentrated on grave finds, which included material from Austria. Bender Jørgensen described those finds, which often came from excavations in the I 9 th century, for the first time.

In our view today of archaeological textiles, especially of old and important collections, we have to take into account their history-what happened to them since they were found. Some parts of that history are quite problematic, but we have to keep in mind that nineteenth-century researchers

53. Desrosiers and Lorquin, 1998 for an overview, followed by Nowik et al., 2005. See also RocheBernard and Ferdière, 1993. Some archaeological pieces were loaned to other museums in order to illustrate the daily life. The Musée d'Aurillac in the Cantal department experimented the only attempt to copy the famous tunic from les Martres-de-Veyre. The fac-simile was woven by Mme Michèle Mallet for an exhibition in 1986. Information on the scientific protocol is lacking. Brulfert, Mallet and Philippon 1985, p. 40-46.

54. Hundt, 1959, 1960.

55. e.g. Hundt 1959, 1974, 1984, 1987.

56. Schlabow, 1937.

57. Bender Jørgensen, 1989, 2005 
and conservators tried to apply state-of-the-art methods to understand and to preserve textiles. Without their attempts, textile archaeology could not have evolved to the discipline that it is today. Late 2oth century innovations such as C14 dating or fibre analysis with Scanning Electron Microscopy have brought possibilities into textile research which the scholars of the I9TH and beginning of the 2oth century would never have dreamt of. Moreover, the Third Science Revolution, ${ }^{58}$ the integration of new and sophisticated analytical techniques like aDNA, mass spectrometer-based protein sequencing and proteomics to strontium isotope into textile research, will enable a new understanding of prehistoric and ancient textiles, their significance for the economy, and technological and social developments of past societies.

\section{References}

Andersson Strand Eva B., Frei Karin M., Gleba Margarita, Mannering Ulla, Nosch Marie-Louise and Skals Irene, "Old Textiles-New Possibilities", European Journal of Archaeology, n 13-2, 2010, p. 149-173.

Audollent Auguste, "Nouvelles fouilles aux Martres-de-Veyre ", Bulletin Historique et Scientifique de l'Auvergne, 1922, p. 260-264.

Audollent Auguste, «Les Tombes Gallo-Romaines à inhumation des Martresde-Veyre (Puy-de-Dôme) ", Mémoires présentés à l'Académie des Sciences et Belles Lettres, no 13, 1923, p. 275-328.

Audollent Auguste, "Les Martres-de-Veyre ", L’Auvergne littéraire et artistique, vol. A, 1924, p. 15-17.

Bender Jørgensen Lise, "European Textiles in Later Prehistory and Early History. A Research Project", Journal of Danish Archaeology, n 8, 1989, p. 144-158.

Bender Jørgensen Lise, "Hallstatt and La Tène Textiles from the Archives of Central Europe ", in Peter Bichler, Karina Grömer, Regina Hofmann de Keijzer, Anton Kern and Hans Reschreiter (dir.), "Hallstatt Textiles". Technical Analysis, Scientific Investigation and Experiment on Iron Age Textiles, Archaeopress, British Archaeological Reports Int. Series 1351, Oxford, 2005, p. 133-150.

Blondel François, "Un cercueil en sapin de l'époque gallo-romaine parfaitement conservé découvert aux Martres-de-Veyre (Puy-de-Dôme) ", in Bertrand Dousteyssier and Philippe Bet (dir.), Éclats arvernes, fragments archéologiques ( $I^{e r}-V^{e}$ siècle ap. J.-C.), Presses universitaires Blaise-Pascal, Clermont-Ferrand, 2014, p. 254-255.

58. Kristiansen 2014; for integration of those techniques into textile research see Andersson Strand et al., 2010, p. 154-158. 
Bouillet Jean-Baptiste, Musée de Clermont-Ferrand (Puy-de-Dôme), Clermont, 1861.

Breniquet Catherine, Beche-Wittmann Marie, Bouilloc Christine et Gaumat Camille, "Une collection textile exceptionnelle : les textiles gallo-romains des Martres-de-Veyre conservés au Musée Bargoin de Clermont-Ferrand ", Artefact. Techniques, histoire et sciences humaines, $\mathrm{n}^{\circ}$ 6, 2017a, p. 197-207.

Breniquet Catherine, Beche-Wittmann Marie, Boullloc Christine et Gaumat Camille, "The Gallo-roman textile collection from Les Martres-deVeyre, France", Archaeological Textile Review, n 59, 2017b, p. 3-13.

Brulfert Elisabeth, Mallet Michèle and Phillipon Anne, Premiers tissus, premiers tisserands, catalog of the exhibition at musée d'Aurillac, 9 November 1985-31 January 1986, Aurillac, 1985.

Calament Florence, "Antinoé. Histoire d'une collection dispersée ", Revue du Louvre, n ${ }^{\circ}$ 5-6, 1989, p. 336-342.

Calament Florence, La révélation d'Antinoé par Albert Gayet. Histoire, archéologie, muséographie, Institut français d'archéologie orientale, Le Caire, 2005.

Calament Florence, «La résurrection d'un coin d'Egypte ignoré ", dans Florence Calament and Maximilien Durand (dir.), Antinoé, à la vie, à la mode. Visions d'élégance dans les solitudes, Fages éditions, Lyon, 2013, p. 24-35.

422 Cortopassi Roberta et Nowik Witold, "Introduction ", Techné, n 41, 2015, p. 5-7.

DeChelette Joseph, Manuel d'archéologie préhistorique, celtique et gallo-romaine 2. Archéologie préhistorique et celtique. Troisième partie: Second àge du fer ou époque de la Tène, Picard, Paris, 1914.

Descamps Sophie, Moulherat Christophe, Beugnot Claire and Spandidaki Stella, « La production textile en Grèce au v $v^{e}$ siècle avant notre ère. Deux nouveaux témoignages attiques conservés au musée du Louvre ", Techné, n ${ }^{41}$, 2015, p. 71-77.

Desrosiers Sophie and Lorquin Armèle, "Gallo-Roman Archaeological Textiles Found in France", in Lise Bender Jørgensen and Christina Rinaldo (dir.), Textiles in European Archaeology, Report from the 6th NESAT Symposium, 7-1 $1^{\text {th }}$ May 1996 in Borås, Göteborg, 1998, p. 53-72.

Fontan Elisabeth and Moulherat Christophe, " Nouvelles découvertes sur les textiles retrouvés dans le sarcophage de la reine de Saddan au Tombeau des Rois (Jérusalem) », Techné, n 41, 2015, p. 25-31.

Fournier Pierre-François, "Patron d'une robe de femme et d'un bas gallo-romain trouvés aux Martres-de-Veyre ", Bulletin historique et scientifique de l'Auvergne, $\mathrm{n}^{\circ}$ LXXVI, 1956, p. 202-203.

Gengler Carine, Prähistorische Textilien aus Hallstatt im Naturhistorischen Museum Wien. Untersuchung - Konservierung - Lagerung, Unpubl. Diplomarbeit, Inst. 
$\mathrm{f}$. Konservierungswissenschaften und Restaurierung, Universität $\mathrm{f}$. Angewandte Kunst Wien, 2005. Unpubl. Hallstatt Textil Report 6, Naturhistorisches Museum Wien, 2005a.

Gengler Carine, "Neues Lagerungskonzept für die Textilien aus Hallstatt ", in Peter Bichler, Karina Grömer, Regina Hofmann de Keijzer, Anton Kern and Hans Reschreiter (dir.), Hallstatt Textiles. Technical Analysis, Scientific Investigation and Experiment on Iron Age Textiles, Archaeopress, British Archaeological Reports, Int. Series 1351, Oxford, 2005b, p. 77-79.

Grenier Albert, Manuel d'archéologie gallo-romaine, tome 1 : Généralités et travaux militaires. Tome 2 : L'Archéologie du sol, les routes, la navigation, l'occupation du sol, Picard, Paris, 1958.

Grömer Karina, "Römische Textilien in Noricum und Westpannonien - im Kontext der archäologischen Gewebefunde 2000 v. Chr. - 500 n. Chr. in Österreich ", Austria Antiqua, n 5, 2014.

Grömer Karina, The Art of Prehistoric Textile Making-The Development of Craft Traditions and Clothing in Central Europe, Veröffentlichungen der Prähistorischen Abteilung 5, Vienna, 2016.

Grömer Karina, Kern Anton, Reschreiter Hans and Rösel-Mautendorfer Helga, Textiles from Hallstatt. Weaving Culture in Bronze and Iron Age Salt Mines. Textilien aus Hallstatt. Gewebte Kultur aus dem bronze- und eisenzeitlichen Salzbergwerk, Archaeolingua 29, Budapest, 2013.

Grömer Karina and Reschreiter Hans, "Chapter 2: Hallstatt-160 years research", in Karina Grömer, Anton Kern, Hans Reschreiter and Helga Rösel-Mautendorfer (dir.), Textiles from Hallstatt. Weaving Culture in Bronze and Iron Age Salt Mines. Textilien aus Hallstatt. Gewebte Kultur aus dem bronzeund eisenzeitlichen Salzbergwerk, Archaeolingua 29, Budapest, 2013, p. 33-52.

Hald Margarete, Ancient Danish Textiles from Bogs and Burials, Aarhus University Press, Aarhus, 1980.

HeIn Rich Angelika, "History of the Department of Prehistory and its collections on display", in Karina Grömer and Anton Kern (dir.), Artifacts. Threasures of the Millennia. A Guide through the Prehistoric Collection. Natural History Museum Vienna Exhibition guide, Verlag des Naturhistorischen Museums, Wien, 2018, p. 8-19.

HundT Hans-Jürgen, «Vorgeschichtliche Gewebe aus dem Hallstätter Salzberg », Jahrbuch des Römisch-Germanischen Zentralmuseums, nº 6, 1959, p. 66-75.

Hundt Hans-Jürgen, «Vorgeschichtliche Gewebe aus dem Hallstätter Salzberg », Jabrbuch des Römisch-Germanischen Zentralmuseums Mainz, n 7, 1960, p. 126-150.

Hundt Hans-Jürgen, " Die Textilreste aus den Gräbern vom Dürrnberg ", in Fritz Moosleitner, Ludwig Pauli and Ernst Penninger (dir.), Der Dürrnberg 
bei Hallein II, Münchner Beiträge zur Vor- und Frühgeschichte 17, 1974, p. $136-142$.

Hundt Hans-Jürgen, "Textilfunde aus Grab 86 des awarischen Friedhofs von Sommerein am Leithagebirge, Niederösterreich ", in Falko DAIM and Andreas LipPert (dir.), Das awarische Gräberfeld von Sommerein am Leithagebirge, NÖ. Studien zur Archäologie der Awaren 1, Vienna, 1984, p. 181-182.

Hundt Hans-Jürgen, "Textilreste aus awarischen Gräbern von Leobersdorf und ein Exkurs über gegossene Textilstrukturen an der Rückseite bronzener Riemenzungen », in Falko DAIM (dir.), Das awarische Gräberfeld von Leobersdorf, NÖ. Studien zur Archäologie der Awaren 3/2, Vienna 1987, p. 9-17.

Kern Anton, Kowarik Kerstin, Rausch Andreas and Reschreiter Hans, "Kingdom of Salt ", Veröffentlichungen der Prähistorischen Abteilung (VPA) 3, Verlag des Naturhistorischen Museums Wien, Wien, 2009.

Kristiansen Kristian, "Towards a New Paradigm? The Third Science Revolution and its Possible Consequences in Archaeology", Current Swedish Archaeology, $\mathrm{n}^{\circ} 22,2014$, p. 11-34.

Lauranson Romain, "Le Bay" et "Le Lot" (Les Martres-de-Veyre, 63). Occupation laténienne. Opération 2012 : bilan de la documentation bibliographique et matérielle, prospections pédestres, Review of thematic prospect, 2012.

Lintz Yannick and Coudert Magali (dir.), Antinoé. Momies, textiles, céramiques et autres antiques. Envois de l'Etat et dépôts du musée du Louvre de 1901 à nos jours, Musée du Louvre et Somogy éditions d'art, Paris, 2013.

Miller (von) Dorothea, Ein archäologischer Textilfund aus Hallstatt. Freilegung mit Unterstützung durch Computertomographie. Vordiplom Sommersemester 2005. Inst. f. Konservierungswissenschaften und Restaurierung-Technologie, Universität für angewandte Kunst Wien, Vienne, 2005.

Morelli Michaela, "Untersuchungen zum Erhaltungszustand der HallstattTextilien (Examination of the state of preservation of the Hallstatt Textiles)", in Peter Bichler, Karina Grömer, Regina Hofmann de Keijzer, Anton Kern and Hans Reschreiter (dir.), Hallstatt Textiles. Technical Analysis, Scientific Investigation and Experiment on Iron Age Textiles, Archaeopress, British Archaeological Reports, Int. Series 1351, Oxford, 2005, p. 73-76.

Nowik Witold, Desrosiers Sophie, Surowiec Izabella et Trojanowicz Marek, "The analysis of dyestuffs from First- to Second Century textile artefacts in the Martres-de-Veyre (France) excavations", Archaeometry, n 47-4, 2005, p. 835-848.

PAGÈs Charles, «Étude technique sur les tissus découverts dans les sépultures gallo-romaines des Martres-de-Veyre ", Mémoires présentés à l'Académie des Sciences et Belles Lettres, $\mathrm{n}^{\circ} 13,1923$, p. 331-384. 
Ramsauer Johann Georg, "Beschreibung mit Abbildungen über die aufgefundenen Altertumsgräber nächst des Rudolfsthurms am Salzberg zu Hallstatt nach den, von den k.k. Bergmeister Johann Georg Ramsauer über diese Funde geführten Tagebuch u.z. Beginn mit Jahr 1846 bis einschlüßig 1849 », Manuskript in der Bibliothek des Kunsthistorischen Museums Wien, Nr, 3185, Hallstatt, 1850. Abschrift in Barth 1990.

Reschreiter Hans, "Chapter 1: The Prehistoric salt-mines of Hallstatt", in Karina Grömer, Anton Kern, Hans Reschreiter and Helga RöselMautendorfer (dir.), Textiles from Hallstatt. Weaving Culture in Bronze and Iron Age Salt Mines. Textilien aus Hallstatt. Gewebte Kultur aus dem bronze- und eisenzeitlichen Salzbergwerk, Archaeolingua 29, Budapest, 2013, p. 13-32.

Reschreiter Hans, "The salt mines of Hallstatt", in Karina GröMer and Anton Kern (dir.), Artifacts. Treasures of the Millennia. A Guide through the Prehistoric Collection. Natural History Museum Vienna Exhibition guide, Verlag des Naturhistorischen Museums, Vienne, 2018, p. 156-176.

Privat-Savigny Maria-Anne, "Vers une restauration scientifique des textiles anciens (xIx ${ }^{\mathrm{e}}$-xx ${ }^{\mathrm{e}}$ siècles)", Techné, $\mathrm{n}^{\circ}$ 41, 2015, p. 65-77.

SaTLOW Anton, "Gutachten über Garnproben der Gewebe 18 und 19", in Hans Jürgen Hundt (dir.), Vorgeschichtliche Gewebe aus dem Hallstätter Salzberg, Jahrbuch des Römisch-Germanischen Zentralmuseums Mainz, nº 6, Verlag des Römisch-Germanischen Zentralmuseums Mainz, Mayence, 1959, p. 96-97.

Schlabow Karl, Germanische Tuchmacher der Bronzezeit, Neumünster, 1937.

Sреснт Walter, «Kriminaltechnisches Gutachten über Garnproben der Gewebe 18 und 19 ", in Hans Jürgen Hundt (dir.), Vorgeschichtliche Gewebe aus dem Hallstätter Salzberg, Jahrbuch des Römisch-Germanischen Zentralmuseums Mainz, n 6, Verlag des Römisch-Germanischen Zentralmuseums Mainz, Mayence, 1959 , p. 97-100.

StAPF Othmar, «Die Pflanzenreste des Hallstätter Heidengebirges», Verhandlungen der zoologisch-botanischen Gesellschaft Wien, 1886, p. 409.

Vogt Emil, Geflechte und Gewebe der Steinzeit, Verlag E. Birkhaiser, Bâle, 1937.

Wells Peter S., The Emergence of an Iron Age Economy. The Mecklenburg Grave Groups from Hallstatt and Stična. American School of Prehistoric Research 33, Peabody Museum of Archaeology and Ethnology, Harvard University, 1981. 


\section{The authors}

Catherine Breniquet is a Professor in Art History and Antique Archeology at Université Clermont Auvergne. Initially an orientalist, part of her research is devoted to the archeology of textile. She is currently the head of the Programme Collectif de Recherches (PCR) "ArchéoMartres" for the study and valorisation of Gallo-roman archeological collections form the necropolis of Les Martres-deVeyre that are kept in the museum Bargoin of Clermont-Ferrand. She has published a book on weaving in Mesopotamy (Essai sur le tissage en Mésopotamie, des premières communautés sédentaires à la fin du IIle millénaire avant J.-C., de Boccard, Paris, 2008) and articles in collaboration with M. Bèche-Wittmann, C. Bouilloc et C. Gaumat ("Une collection textile exceptionnelle : les textiles gallo-romains des Martres-de-Veyre conservés au Musée Bargoin de Clermont-Ferrand", Artefact. Techniques, histoire et sciences humaines, n 6, 2018, p. 197-207 ; "What do we know about the Gallo-roman textile collection from Les Martres-de-Veyre, France?", Archaeological Textile Review, 59, 2017, p. 71-81). Contact: catherine. breniquet@uca.fr

Karina Grömer is the vice-head of the Department of Prehistory, Natural History Museum Vienna. She studied Prehistoric Archaeology, Ethnology and Anthropology at the University of Vienna in Austria. Habilitation thesis: "Archaeological Textile Research-Technical, economic and social aspects of textile production and clothing from Neolithic to the Early Modern Era". She is specialized on interdisciplinary and integrated analysis of textiles, research on textile tools and reconstruction of prehistoric costume. Her research covers a timespan from c. $2500 \mathrm{BC}$ till $1000 \mathrm{AD}$ and a geographical area from Central Europe to Iran (research projects e.g. "DressID-Clothing and Identity in Roman Empire", "CinBA-Creativity in the Bronze Age" and "Chehrabad Saltmummy \& Saltmine Exploration Project"). She is also teaching at the Universities Vienna (Austria), Brno (Czech Republic) and Southampton (Great Britain). Contact: karina. groemer@nhm-wien.ac.at 